\title{
The Antibacterial Effect of Ethanol Extract of Polish Propolis on Mutans Streptococci and Lactobacilli Isolated from Saliva
}

\author{
Arkadiusz Dziedzic, ${ }^{1}$ Robert Kubina, ${ }^{2}$ Robert D. Wojtyczka, ${ }^{3}$ Agata Kabała-Dzik, \\ Marta Tanasiewicz, ${ }^{1}$ and Tadeusz Morawiec ${ }^{4}$ \\ ${ }^{1}$ Department of Conservative Dentistry with Endodontics, Division of Medicine and Dentistry, Medical University of Silesia, \\ Pl. Akademicki 17, 41-902 Bytom, Poland \\ ${ }^{2}$ Department of Pathology, School of Pharmacy and Laboratory Medicine, Medical University of Silesia, ul. Ostrogorska 30, \\ 41-200 Sosnowiec, Poland \\ ${ }^{3}$ Department and Institute of Microbiology and Virology, School of Pharmacy and Laboratory Medicine, Medical University of Silesia, \\ ul. Jagiellońska 4, 41-200 Sosnowiec, Poland \\ ${ }^{4}$ Department of Oral Surgery, Division of Medicine and Dentistry, Medical University of Silesia, Pl. Akademicki 17, \\ 41-902 Bytom, Poland
}

Correspondence should be addressed to Arkadiusz Dziedzic; adziedzic@sum.edu.pl

Received 10 January 2013; Revised 5 February 2013; Accepted 25 February 2013

Academic Editor: Zenon Czuba

Copyright (C) 2013 Arkadiusz Dziedzic et al. This is an open access article distributed under the Creative Commons Attribution License, which permits unrestricted use, distribution, and reproduction in any medium, provided the original work is properly cited.

\begin{abstract}
Dental caries occurrence is caused by the colonization of oral microorganisms and accumulation of extracellular polysaccharides synthesized by Streptococcus mutans with the synergistic influence of Lactobacillus spp. bacteria. The aim of this study was to determine ex vivo the antibacterial properties of ethanol extract of propolis (EEP), collected in Poland, against the main cariogenic bacteria: salivary mutans streptococci and lactobacilli. The isolation of mutans streptococci group bacteria (MS) and Lactobacillus spp. (LB) from stimulated saliva was performed by in-office CRT bacteria dip slide test. The broth diffusion method and AlamarBlue assay were used to evaluate the antimicrobial activity of EEP, with the estimation of its minimum inhibitory concentration (MIC) and minimum bactericidal concentration (MBC). The biochemical composition of propolis components was assessed. The mean MIC and MBC values of EEP, in concentrations ranging from $25 \mathrm{mg} / \mathrm{mL}$ to $0.025 \mathrm{mg} / \mathrm{mL}$, for the MS and LB were found to be $1.10 \mathrm{mg} / \mathrm{mL}$ versus $0.7 \mathrm{mg} / \mathrm{mL}$ and $9.01 \mathrm{mg} / \mathrm{mL}$ versus $5.91 \mathrm{mg} / \mathrm{mL}$, respectively. The exposure to an extract of Polish propolis affected mutans streptococci and Lactobacillus spp. viability, exhibiting an antibacterial efficacy on mutans streptococci group bacteria and lactobacilli saliva residents, while lactobacilli were more susceptible to EEP. Antibacterial measures containing propolis could be the local agents acting against cariogenic bacteria.
\end{abstract}

\section{Introduction}

Dental caries, the most prevalent disease affecting humans, continues to be a common and global public health problem, in spite of confirmed decline in some parts of the world. Caries etiology, with the main focus on oral microbiology and cariogenic bacteria, is central to understanding the potential opportunities for and likely impact of new antimicrobial agents to reduce the caries burden worldwide. Prevention and control of dental caries activity is not restricted to a single technique but includes regular check-ups, routine use of fluoride-containing toothpastes, decreased sugar intake, topical fluorides application, and at-home rinsing with antiplaque and antibacterial solutions.

Over the last several years, a worldwide trend has been observed in the use of natural products, due to their provenby-evidence pharmacological effect on oral cavity environment in terms of efficient caries prevention. This tendency may be also applied to "over-the-counter" therapeutic and prophylactic products which are recommended for caries control and oral health maintenance. Propolis, a natural substance produced by honeybees, which has been widely 
consumed in the folk medicine since ancient times, seems to be a promising ingredient of topical formulations due to its multidirectional biological properties [1]. Apart from antibacterial activity, various studies have demonstrated that propolis has other beneficial properties, such as antioxidative, antifungal, antiviral, and anti-inflammatory ones [2,3]. Additionally, antiproliferative action in human tumor cell lines has been observed [4-7].

Ethanol extract of propolis (EEP), an effective antimicrobial and anti-inflammatory agent, has been used commercially on the market as a component of toothpaste, mouth rinses, lozenges, and so forth. It is confirmed [8-11] that EEP demonstrates antimicrobial activity against Grampositive cocci of Streptococcus mutans, a facultative anaerobic bacterium commonly found in human oral cavity (saliva and dental plaque) and a main contributor to tooth decay caused by biofilm formation. However, in medicine and dentistry, it still remains an underestimated compound. Relatively few studies were aimed at the influence of EEP on the growth of Lactobacillus spp. bacteria [12, 13], a second significant contributor to dental caries progression, acting in second stage of tooth decay development as a coexisting factor. Therefore, further investigations are needed to validate a dose required to eliminate cariogenic microorganisms within the oral cavity, avoiding local or systemic adverse reactions at the same time.

Propolis, a semisolid mixture of organic resin and wax, produced by honeybees (Apis mellifera), is used by bees to seal their honeycombs and to protect the entrance against intruders. It is assumed that the chemical composition of propolis comprises approximately $50 \%$ of resin and vegetable balm, $30 \%$ of wax, $10 \%$ of essential and aromatic oils, $5 \%$ of pollens, and $5 \%$ of other trace substances, including organic debris, depending on the place and time of collection [14, 15]. The constituents of propolis vary widely, depending on the climate, season, location, or year, and its chemical composition is not stable $[14,16]$.

Various aromatic compounds, mainly flavonoids and phenolics, seem to be the pharmacologically active constituents in propolis [17-19], which are well-known plant compounds that have unique and multidirectional antioxidant, antibacterial, antifungal, anti-inflammatory, and immunomodulative properties [20-22]. As an antiinflammatory agent, propolis stimulates the immune system by promoting phagocytic activity and cellular immunity $[23,24]$ and improves the healing effects on epithelial tissues [14]. Additionally, propolis contains nonspecific elements, such as iron and zinc that are important for collagen synthesis [25]. Since some of the constituents composing synthetic cariostatic measures may cause adverse effects, there is an increased need to screen for new antimicrobial agents, which may act against plaque formation and against cariogenic bacteria. The bacteriostatic, bactericidal, and antiadherent activities of propolis on microorganisms connected with dental caries suggest its significant influence on dental caries control within the oral cavity environment $[12,13,26]$. The available extensive studies are mainly concerned with the mainly well-known "red" and "green" propolis, and the biochemical assays of Polish propolis compound are not yet common [27], in terms of its anticariogenic activity and biological effect on oral microorganisms. Moreover, the phenolic and flavonoid profile of propolis from the Southeast of Poland has not been thoroughly described yet.

Selected group of oral streptococci is closely related to Streptococcus mutans and is referred to as the "mutans group" or the "mutans streptococci" [28]. Only two cariogenic species from the "mutans group", Streptococcus mutans and Streptococcus sobrinus, are found commonly in human oral environment. The others were isolated in various animals (rats, macaque monkeys) [29]. Distinguishing of S. mutans and $S$. sobrinus in saliva by appropriate laboratory tests, to identify to the single species level, is rarely practicable, particularly in large-scale epidemiological studies. Most scientific sources regarding the relationship between oral streptococci and caries have considered the two species together as the mutans streptococci (MS). Because of a greater prevalence, most of the isolates are described as $S$. mutans, and sometimes the single name $S$. mutans is used erroneously, even though there was no investigation towards $S$. sobrinus presence and isolation. In the past, most papers were referred to $S$. mutans because $S$. sobrinus was not officially recognized.

The study aimed at investigating in vitro the antimicrobial activity of ethanol extract of Polish propolis against two main cariogenic oral pathogens with its effects on the mutans streptococci and lactobacilli growth. The solution prepared with propolis extract was also analyzed for its biochemical content and its qualitative antibacterial potential. The determination of optimal concentration of the Polish propolis against the clinical isolates from the saliva can support the development of the oral hygiene products, such as gargling solution and toothpastes.

\section{Material and Methods}

2.1. Preparation of Ethanol Extract of Propolis. Propolis samples were produced by honeybees (Apis mellifera) from the apiary in Kamianna (Nowy Sacz Voivodeship, south of Poland) which constituted the material for the research. The tree population in the area consists primarily of the black poplar (Populus nigra), birch (Betula alba), alder (Alnus glutinosa), beech (Fagus sylvatica), and horsechestnut (Aesculus hippocastanum). Hand-collected propolis was kept desiccated and in the dark before its processing. The samples were ground mechanically and bottled in $10 \mathrm{~g}$ portions. The portions of $10 \mathrm{~g}$ were put into flasks, and $100 \mathrm{~g}$ of $70 \%$ ethanol (w/v, POCH S.A., Poland) was added. Propolis was subjected to 14 days of extraction in order to obtain ethanol extract of propolis (EEP). The flask was placed in laboratory shaker in a dark, closed bottle for the time of two weeks in room temperature. After that time, the extract was cooled in $4^{\circ} \mathrm{C}$ for 24 hours in order to precipitate all insoluble substances. Rough particles were removed from the propolis extract by filter and filtered through filter paper (Whatman no. 4, UK). The filtrate obtained that way was evaporated, using rotary vacuum evaporator (Rotavapor R-215, BUCHI Labortechnik AG, Switzerland), in $40^{\circ} \mathrm{C}$. This way, a viscous substance having brown colour was obtained, which was later dissolved 
in ethanol in order to receive $100 \mathrm{mg} / \mathrm{mL}$ of the working concentration.

2.2. Cariogenic Bacteria Isolation. The isolation and estimation of bacterial growth of mutans streptococci (MS) and Lactobacillus spp. (LB) was performed by means of semiquantitative method, using a dip slide, commercial screening CRT bacteria medium (Ivoclar-Vivadent, Liechtenstein). Seventeen adult subjects, aged 27-54, who were involved in this study, underwent a routine dental treatment at Department of Conservative Dentistry with Endodontics and at Academic Center of Dentistry and Specialist Medicine, Medical University of Silesia, Bytom, Poland. Inclusion criteria for the research group were based on medical and dental history, socioeconomic status, analysis of clinical documentation, assessment of oral hygiene (plaque indexes), and dental charting profile (DMFT index $>3$ ). The exclusions criteria comprised current treatment with antibiotics, the use of antibacterial mouth rinse or antiseptic lozenges, acute oral infections, and the severely decreased saliva flow (dry mouth syndrome). None of the participants refused to take part in the study, and informed consent for all patients was obtained, including adequate information to meet necessary requirements for the study.

CRT bacteria chair side test was used to isolate the mutans streptococci and lactobacilli from saliva, by means of selective culture media. Findings of $100.000 \mathrm{CFU}$ or more of MS and LB per $1 \mathrm{~mL}$ of saliva indicate high caries risk. The indication of CRT bacteria includes in vitro diagnostics of the main cariogenic microbiota in saliva. The bright green agar surface is designed for the determination of LB count in saliva and the blue agar surface for determination of MS count in saliva, or plaque (MSB Agar). Diagnostic kits and selective media, designed for use in the dental clinic for isolating caries-related microorganisms, are based on selective media, and they are measuring total mutans streptococci count, not just Streptococcus mutans species. They may contain the specific ingredients, including antibiotics (bacitracin), which suppress the growth of most species but allows $S$. mutans and S. sobrinus to grow.

The investigator collected stimulated saliva from each individual, according to the manufacturer's specification. Saliva samples were stimulated with paraffin-based sticks (1 minute) and collected into sterile flasks ( $2 \mathrm{~mL}$ on the average). The tablets of $\mathrm{NaHCO}_{3}$ were placed at the bottom of the vials. All samples were collected within a single working day ( 9 hours, from 9.00 till 18.00) by the same examiner, using the same technique and procedure. The vials were then immediately seeded in the laboratory based in Department and Institute of Microbiology and Virology (Sosnowiec, Poland), Medical University of Silesia. The test vials were placed upright in the incubator and incubated at $37^{\circ} \mathrm{C} / 99^{\circ} \mathrm{F}$ for 48 hours. After removal of the vial from the incubator, the density of the MS and LB colonies was compared with the corresponding evaluation pictures in the enclosed model chart. The values of $<10^{5}$ and $>10^{5}$ were recorded for the low and high CFU ranking, based on the scale provided in the CRT kit (Ivoclar-Vivadent, Liechtenstein). Each sample was examined by the same viewer. Bacteria strains, mutans streptococci and Lactobacillus spp. isolated from clinical specimens, were subjected to further inoculation.

\subsection{Determination of Minimum Inhibitory Concentration} (MIC) and Minimum Bactericidal Concentration (MBC). In order to establish the minimum inhibitory concentration (MIC) and the minimum bactericidal concentration (MBC) of isolated mutans streptococci and lactobacilli, the broth dilution method was used, as recommended by the Clinical and Laboratory Standards Institute [30, 31]. The minimum inhibitory concentration (MIC) was determined as the lowest concentration of the propolis extract, which inhibited the growth of the tested microorganisms. The MBC was defined as the lowest concentration of antimicrobial agents required to eradicate a particular bacterium. The MIC value has been determined by incubation of the isolated strains in 96well microplates for 24 hours, at the temperature of $37^{\circ} \mathrm{C}$. The bacterial inoculum has been prepared in $0.9 \%$ sodium chloride (POCH S.A., Poland) from fresh cultures. MIC value was estimated by visual and spectroscopic method by absorbance measurement at $600 \mathrm{~nm}$ (OD600-optical density reading at $600 \mathrm{~nm}$ ).

The turbidity of the suspension has been adjusted to the McFarland 0.5 turbidity standard (Densi-La-Meter II, Erba Lachema, Brno, Czech Republic), and the inoculum has been diluted $(1: 100)$ in sterile medium. Serial two-fold dilutions of EEP have been prepared in Mueller-Hinton Broth II (MHB, Oxoid Ltd, Basingstone, Hempshire, UK), and ethanol was used as controls. The microorganisms have been exposed to serial dilutions of ethanol extract of propolis, within the range of $25 \mathrm{mg} / \mathrm{mL}$ to $0.025 \mathrm{mg} / \mathrm{mL}$. The maximum concentration $25 \mathrm{mg} / \mathrm{mL}$ was then excluded from the experimental protocol. The inoculum size has been verified by plating serial dilutions of the inoculum and performing colony counts. The values of minimum and maximum MIC have been determined, as well as $\mathrm{MIC}_{50}$ and $\mathrm{MIC}_{90}$.

In order to determine the $\mathrm{MBC}$ value, from the MIC concentration and two higher concentrations, $10 \mu \mathrm{L}$ of the medium have been collected and transferred to $10 \mathrm{~mL}$ of sterile physiological saline. Subsequently, a series of three dilutions have been performed, in the proportion of 1:10. From each dilution, $100 \mu \mathrm{L}$ have been collected and disseminated on Mueller-Hinton medium, with the addition of 5\% of ram blood, using surface culture method. The entire stuff incubated for $24 \mathrm{~h}$ in the temperature of $37^{\circ} \mathrm{C}$. Petri dishes on which the number of colonies grown has been less than 300 have been considered for assessment. MBC has been considered achieved when a $99.9 \%$ reduction of the number of colonies has been achieved, in comparison with control. The control test has been carried out in an analogous way, with the addition of EEP.

2.4. AlamarBlue Susceptibility Colorimetric Assay. Planktonic susceptibility testing of mutans streptococci has been performed by the reference broth microdilution assay, using round-bottom, polystyrene, nontissue culture-treated microtiter microplates, and cation-adjusted Mueller-Hinton 
TABLE 1: Mean MIC values of mutans streptococci and lactobacilli for each sample.

\begin{tabular}{|c|c|c|c|c|c|c|}
\hline $\begin{array}{l}\text { Sample no. (mutans } \\
\text { streptococci) }\end{array}$ & $\begin{array}{l}\text { Mean MIC } \\
(\mathrm{mg} / \mathrm{mL})\end{array}$ & $\begin{array}{c}\text { Mean AlamarBlue } \\
\text { MIC for SM } \\
(\mathrm{mg} / \mathrm{mL})\end{array}$ & $\begin{array}{l}\text { CRT bacteria } \\
\quad(\mathrm{CFU})\end{array}$ & $\begin{array}{c}\text { Sample no. } \\
\text { (Lactobacillus spp.) }\end{array}$ & $\begin{array}{c}\text { Mean MIC } \\
(\mathrm{mg} / \mathrm{mL})\end{array}$ & $\begin{array}{l}\text { CRT bacteria } \\
\text { (CFU) }\end{array}$ \\
\hline 1 & 0.78 & 1.56 & $<10^{5}$ & 1 & 0.20 & $<10^{5}$ \\
\hline 2 & 1.56 & 3.12 & $<10^{5}$ & 2 & 0.39 & $<10^{5}$ \\
\hline 3 & 1.56 & 3.12 & $<10^{5}$ & 3 & 0.78 & $<10^{5}$ \\
\hline 4 & 0.78 & 1.56 & $<10^{5}$ & 4 & 0.39 & $<10^{5}$ \\
\hline 5 & 0.78 & 0.78 & $<10^{5}$ & 5 & 0.78 & $<10^{5}$ \\
\hline 6 & 1.56 & 3.12 & $>10^{5}$ & 6 & 0.39 & $>10^{5}$ \\
\hline 7 & 1.56 & 3.12 & $<10^{5}$ & 7 & 0.39 & $>10^{5}$ \\
\hline 8 & 0.78 & 0.78 & $<10^{5}$ & 8 & 0.78 & $<10^{5}$ \\
\hline 9 & 1.56 & 6.25 & $<10^{5}$ & 9 & 1.56 & $>10^{5}$ \\
\hline 10 & 1.56 & 3.12 & $<10^{5}$ & 10 & 0.78 & $>10^{5}$ \\
\hline 11 & 0.39 & 1.56 & $<10^{5}$ & 11 & 0.78 & $<10^{5}$ \\
\hline 12 & 1.56 & 3.12 & $<10^{5}$ & 12 & 0.78 & $<10^{5}$ \\
\hline 13 & 0.39 & 0.20 & $>10^{5}$ & 13 & 0.78 & $>10^{5}$ \\
\hline 14 & 1.56 & 0.78 & $<10^{5}$ & 14 & 0.78 & $<10^{5}$ \\
\hline 15 & 0.78 & 0.78 & $<10^{5}$ & 15 & 0.78 & $<10^{5}$ \\
\hline 16 & 0.78 & 3.12 & $>10^{5}$ & 16 & 0.78 & $>10^{5}$ \\
\hline 17 & 0.78 & 1.56 & $<10^{5}$ & 17 & 0.78 & $<10^{5}$ \\
\hline
\end{tabular}

TABLE 2: MIC values of ethanol extract of propolis for MS $(n=17)$ and LB $(n=17)$ isolated from human saliva.

\begin{tabular}{|c|c|c|c|c|c|c|}
\hline Cariogenic pathogens & $\begin{array}{c}\text { Mean MIC } \pm \text { SD } \\
(\mathrm{mg} / \mathrm{mL})\end{array}$ & $\begin{array}{l}\text { Min MIC } \\
(\mathrm{mg} / \mathrm{mL})\end{array}$ & $\begin{array}{c}\text { Max MIC } \\
(\mathrm{mg} / \mathrm{mL})\end{array}$ & $\mathrm{MIC}_{50}(\mathrm{mg} / \mathrm{mL})$ & $\mathrm{MIC}_{90}(\mathrm{mg} / \mathrm{mL})$ & $\begin{array}{c}\% \text { Susceptible } \\
\text { bacteria }^{*}\end{array}$ \\
\hline Mutans streptococci & $1.10 \pm 0.45$ & 0.39 & 1.56 & 0.78 & 1.56 & 100 \\
\hline Lactobacillus spp. & $0.7 \pm 0.29$ & 0.20 & 1.56 & 0.78 & 0.78 & 100 \\
\hline Cariogenic pathogens & $\begin{array}{c}\text { Mean AlamarBlue } \\
\text { MIC } \pm \text { SD } \\
(\mathrm{mg} / \mathrm{mL}) \\
\end{array}$ & $\begin{array}{c}\text { Min } \\
\text { AlamarBlue } \\
\text { MIC }(\mathrm{mg} / \mathrm{mL})\end{array}$ & $\begin{array}{c}\text { Max } \\
\text { AlamarBlue } \\
\text { MIC }(\mathrm{mg} / \mathrm{mL}) \\
\end{array}$ & $\begin{array}{c}\text { AlamarBlue } \\
\mathrm{MIC}_{50}(\mathrm{mg} / \mathrm{mL})\end{array}$ & $\begin{array}{l}\text { AlamarBlue } \mathrm{MIC}_{90} \\
(\mathrm{mg} / \mathrm{mL})\end{array}$ & $\begin{array}{c}\text { \% Susceptible } \\
\text { bacteria }^{*}\end{array}$ \\
\hline Mutans streptococci & $2.13 \pm 1.53$ & 0.16 & 6.25 & 1.56 & 3.12 & 100 \\
\hline
\end{tabular}

II Broth, as an additional method for $\mathrm{MIC} / \mathrm{MBC}$ validation. After 24 hours of incubation, from each dilution of a volume $100 \mu \mathrm{L}$ have been collected, transferred on the microplates, and $5 \mu \mathrm{L}$ AlamarBlue (Invitrogen, US) was added to the wells $(105 \mu \mathrm{L}$ total volume $=100 \mu \mathrm{L}$ of Mueller-Hinton II Broth, $\mathrm{EEP}$, bacteria $+5 \mu \mathrm{L}$ AlamarBlue). The microplates were shaken gently and incubated for $2 \mathrm{~h}$ at $37^{\circ} \mathrm{C}$. The plates were gently shaken again, and absorbance at $570 \mathrm{~nm}$ and $600 \mathrm{~nm}$ was obtained in a Multiskan EX microplate reader (Thermo Scientific, USA).

For experiments with multiple time points, the microplates were kept in an incubator at $37^{\circ} \mathrm{C}$ between absorbance readings. Controls included media alone, media plus AlamarBlue (AB), media plus AlamarBlue plus propolis dilution, and cells plus media plus AlamarBlue. The percentage reduction of AlamarBlue (\%AB) was calculated using the manufacturer's formula, with replacement of the negative control, which contains only media plus AlamarBlue, with a more robust negative control, media plus AlamarBlue plus a drug concentration equal for each experimental well:

$$
\frac{\left(\varepsilon_{\mathrm{OX}}\right)_{\lambda_{2}} A_{\lambda_{1}}-\left(\varepsilon_{\mathrm{OX}}\right)_{\lambda_{1}} A_{\lambda_{2}}}{\left(\varepsilon_{\mathrm{OX}}\right)_{\lambda_{2}} A_{\lambda_{1}}^{o}-\left(\varepsilon_{\mathrm{OX}}\right)_{\lambda_{1}} A_{\lambda_{2}}^{o}} \times 100 .
$$

In the formula, $\varepsilon_{\lambda_{1}}$ and $\varepsilon_{\lambda_{2}}$ are constants representing the molar extinction coefficient of $\mathrm{AB}$ at 570 and $600 \mathrm{~nm}$, respectively, in the oxidized ( $\varepsilon_{\mathrm{OX}}$ ) form. $A_{\lambda_{1}}$ and $A_{\lambda_{2}}$ represent absorbance of test wells at 570 and $600 \mathrm{~nm}$, respectively. $A_{\lambda_{1}}^{o}$ and $A_{\lambda_{2}}^{o}$ represent absorbance of positive control wells at 570 and $600 \mathrm{~nm}$, respectively. The values of \%AB reduction were corrected for background values of negative controls containing medium without cells.

Assays were performed at least twice, and the average percentage reduction was used to determine the MIC. AlamarBlue MIC was defined as the lowest ethanol extract of propolis concentration resulting in $\leq 50 \%$ reduction of $\mathrm{AB}$ 


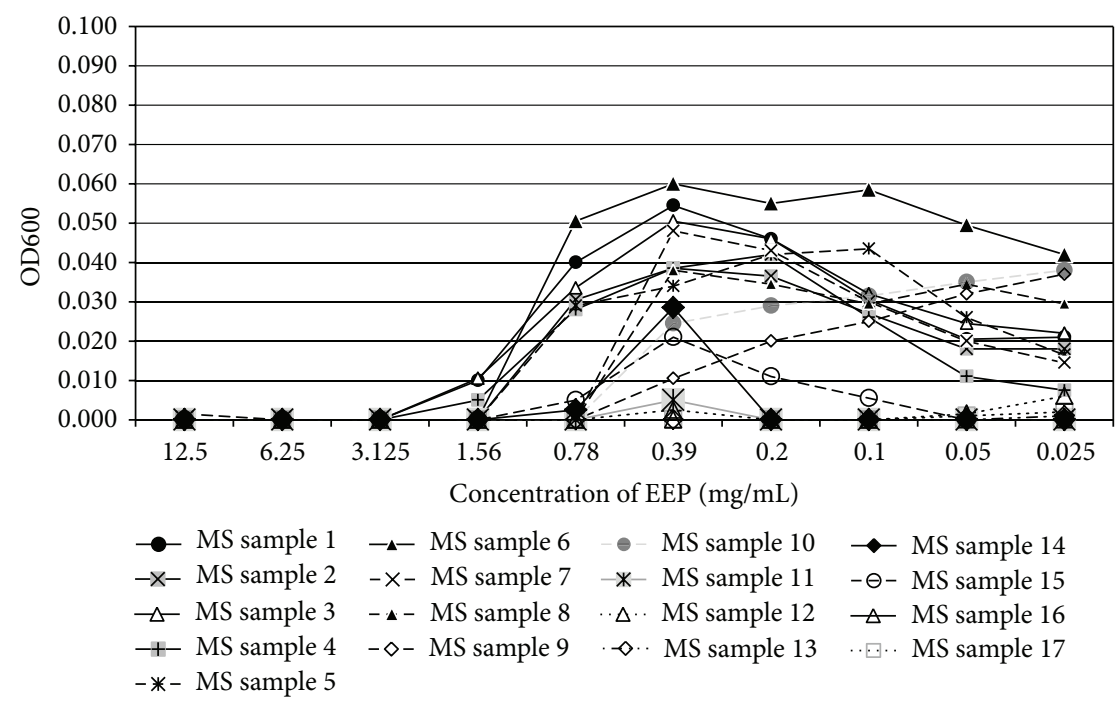

FIGURE 1: The influence of different concentrations of EEP on absorbance changes for MS $(n=17)$ during 1 hour of EEP activity (OD600optical density reading at $600 \mathrm{~nm}$ ).

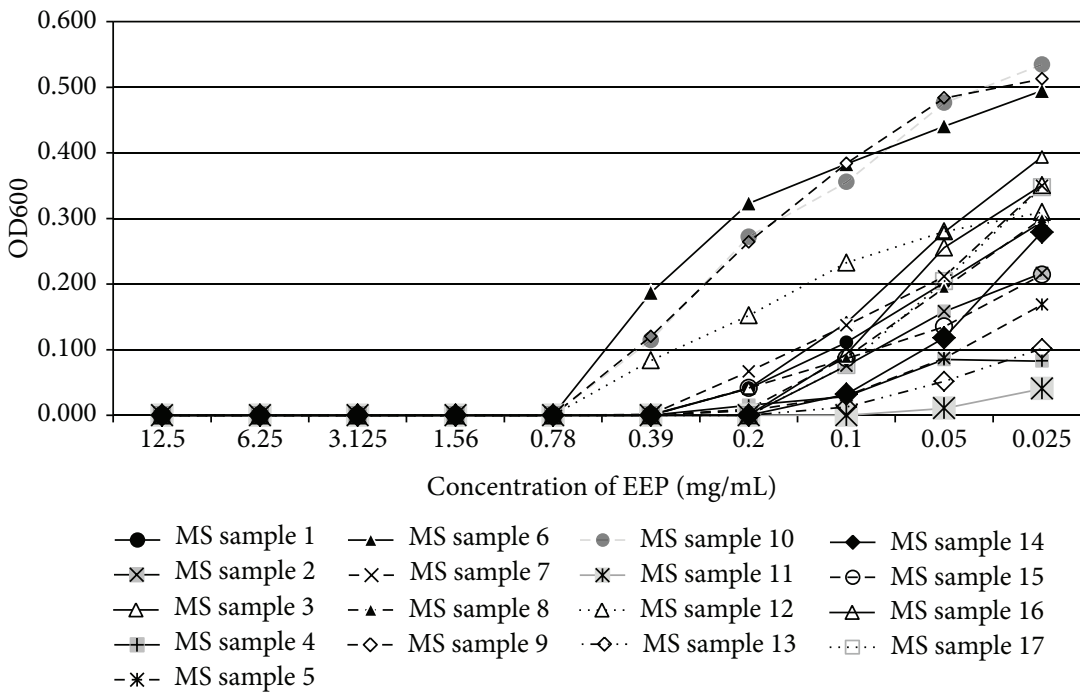

FIGURE 2: The influence of different concentrations of EEP on absorbance changes for MS $(n=17)$ during 4 hours of EEP activity (OD600optical density reading at $600 \mathrm{~nm}$ ).

(average of two experiments) and a purple/blue well 120 minutes after the addition of $\mathrm{AB}$.

2.5. Biochemical Assay of Polyphenolic and Flavonoid Constituents. The total polyphenolic content in propolis was determined using the Folin-Ciocalteu colorimetric method (Spekol 11, Carl Zeiss, Jena, Germany). A reference mixture of pinocembrin and galangin (2:1, w/w, Sigma-Aldrich, USA) was prepared, after it was further diluted into a series of appropriate concentrations (from 0.021 to $0.335 \mathrm{mg} / \mathrm{mL}$ ) that were used for the calibration curve. One $\mathrm{mL}$ of the test solution was transferred to a $50 \mathrm{~mL}$ volumetric flask, containing $15 \mathrm{~mL}$ distilled water. Then, $4 \mathrm{~mL}$ of the Folin-Ciocalteu reagent (Merck Millipore, USA) and $6 \mathrm{~mL}$ of a $20 \%$ sodium carbonate solution were added. The volume was adjusted to $50 \mathrm{~mL}$ with distilled water. The colorimetric absorbance was measured at $760 \mathrm{~nm}$ after $2 \mathrm{~h}$.

The total flavonoid content was determined by quantification of the flavones/flavonols and flavanone/dihydroflavonols [32]. Stock standard solutions of galangin $(0.04 \mathrm{mg} / \mathrm{mL})$ for flavones/flavonols assay and pinocembrin $(1 \mathrm{mg} / \mathrm{mL})$ for the flavanone/dihydroflavonols assay were prepared in order to construct the calibration curves. The series of five dilutions in the range of $0.005-0.04 \mathrm{mg} / \mathrm{mL}$ for galangin and $0.1-$ $0.8 \mathrm{mg} / \mathrm{mL}$ for pinocembrin were also prepared.

An aliquot of $1 \mathrm{~mL}$ of the test solution and $0.5 \mathrm{~mL}$ of $5 \%$ aluminum chloride (POCH S.A., Poland) in methanol (POCH S.A., Poland) were mixed in a flask containing $10 \mathrm{~mL}$ of methanol. The volume was adjusted to $25 \mathrm{~mL}$ with 


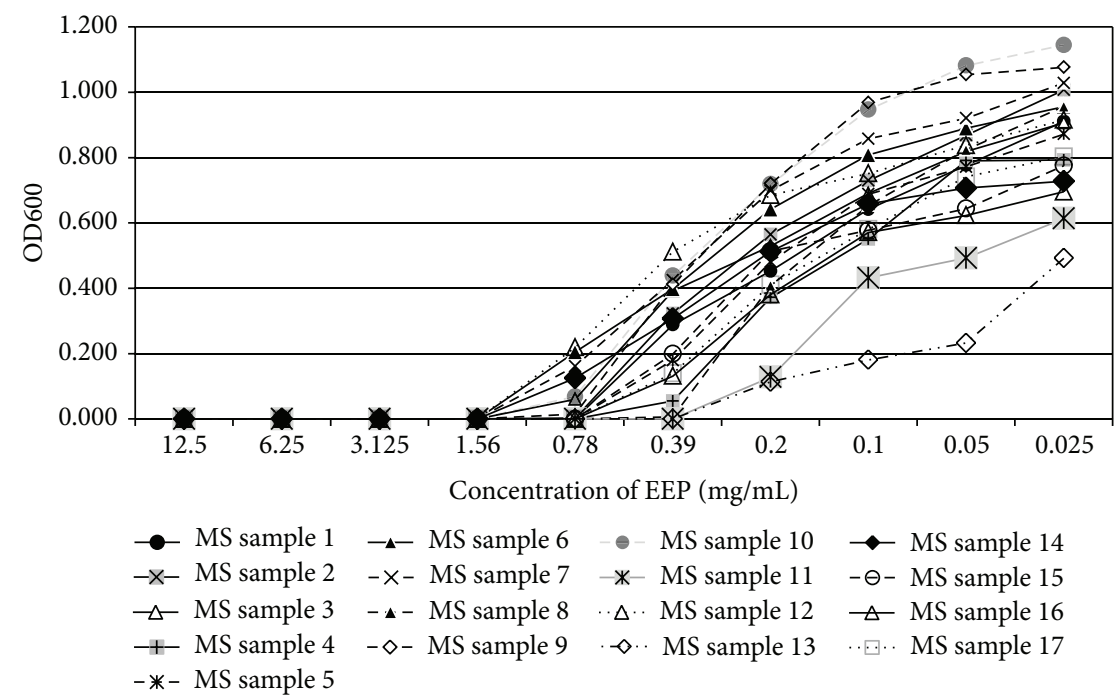

FIGURE 3: The influence of different concentrations of EEP on absorbance changes for MS ( $n=17)$ during 24 hours of EEP activity (OD600optical density reading at $600 \mathrm{~nm})$.

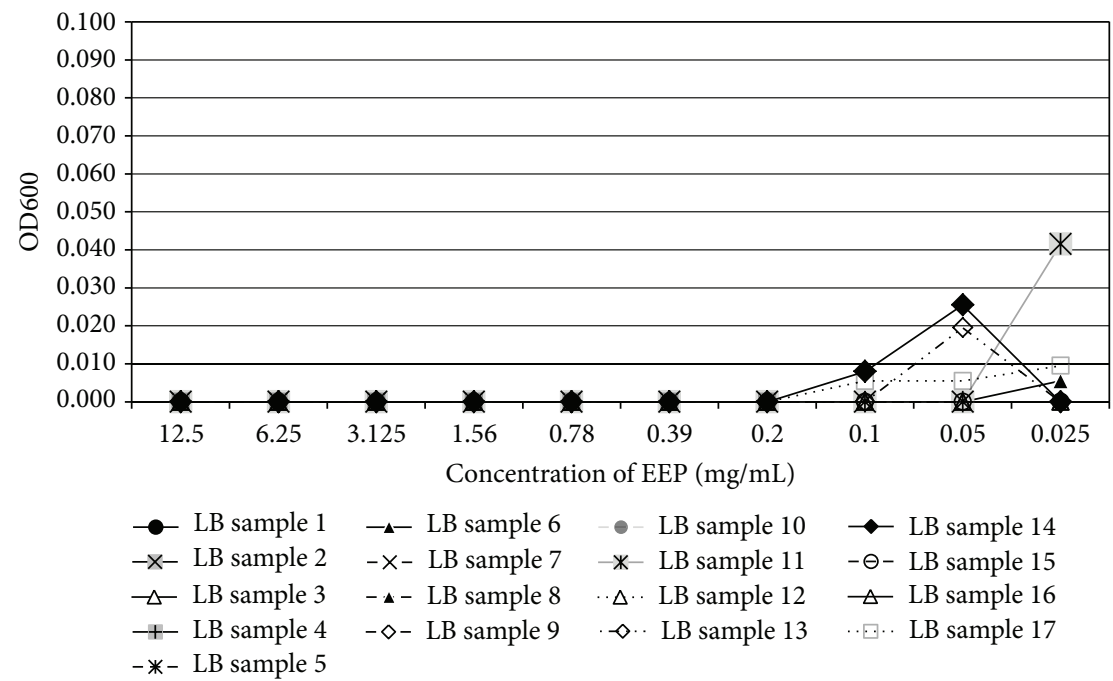

FIGURE 4: The influence of different concentrations of EEP on absorbance changes for Lactobacillus spp. $(n=17)$ during 1 hour of EEP activity (OD600-optical density reading at $600 \mathrm{~nm}$ ).

methanol; after 30 minutes the absorbance was measured at $425 \mathrm{~nm}$ against the blank in order to quantify flavones/ flavonols. An aliquot of the initial extract of propolis $(1 \mathrm{~mL})$ and $2 \mathrm{~mL}$ of 2,4-Dinitrophenylhydrazine solution (POCH S.A., Poland, $1 \mathrm{~g}$ of DNP was mixed with $2 \mathrm{~mL}$ of $96 \%$ sulphuric acid and diluted to $100 \mathrm{~mL}$ with methanol) were heated at $50^{\circ} \mathrm{C}$ for $50 \mathrm{~min}$. After cooling down to room temperature, the solution was diluted to $10 \mathrm{~mL}$ with $10 \%$ potassium hydroxide methanolic solution (POCH S.A., Poland). Half of the one $\mathrm{mL}$ of the solution was transferred into a volumetric flask, and the volume was adjusted to $25 \mathrm{~mL}$ with methanol. The absorbance was measured at $486 \mathrm{~nm}$ against the blank, in order to quantify flavanones and dihydroflavonols.

Blank solutions were prepared by replacing the sample with an equivalent aliquot of methanol that was carried out through all the steps of the applied procedure. The results obtained are presented as percentage \pm standard deviation $( \pm$ SD). The content of other phenols was assessed by subtracting the content of total flavonoids from the content of total polyphenols.

\section{Results}

In the present study, the examined extract of Polish propolis with ethanol demonstrated in vitro antimicrobial activity against main cariogenic bacteria, that is, mutans streptococci group and Lactobacillus spp. (Tables 1, 2, 3, and 4). The exposure of microorganisms to propolis $(0.025-24 \mathrm{mg} / \mathrm{mL})$ for $24 \mathrm{~h}$ affected bacteria viability, as was measured and 
TABLE 3: Mean values of MBC for mutans streptococci and Lactobacillus spp. for each sample.

\begin{tabular}{lccc}
\hline Sample no. (mutans streptococci) & Mean MBC $(\mathrm{mg} / \mathrm{mL})$ & Sample no. (Lactobacillus spp.) & Mean MBC (mg/mL) \\
\hline 1 & 6.25 & 1 & 0.39 \\
2 & 12.5 & 2 & 12.5 \\
3 & 12.5 & 3 & 12.5 \\
4 & 3.13 & 4 & 1.56 \\
5 & 6.25 & 5 & 3.13 \\
6 & 12.5 & 6 & 12.5 \\
7 & 12.5 & 7 & 1.56 \\
8 & 3.13 & 8 & 3.13 \\
9 & 12.5 & 9 & 6.25 \\
10 & 12.5 & 10 & 6.25 \\
11 & 6.25 & 11 & 6.25 \\
12 & 12.5 & 12 & 6.25 \\
13 & 3.13 & 13 & 3.13 \\
14 & 6.25 & 14 & 6.25 \\
15 & 12.5 & 15 & 6.25 \\
17 & 12.5 & 16 & 6.25 \\
\end{tabular}

TABLE 4: MBC values of ethanol extract of propolis for mutans streptococci $(n=17)$ and Lactobacillus spp. $(n=17)$ isolated from human saliva.

\begin{tabular}{lcccccc}
\hline $\begin{array}{l}\text { Cariogenic } \\
\text { pathogens }\end{array}$ & $\begin{array}{c}\text { Mean MBC } \pm \text { SD } \\
(\mathrm{mg} / \mathrm{mL})\end{array}$ & $\begin{array}{c}\text { Min MBC } \\
(\mathrm{mg} / \mathrm{mL})\end{array}$ & $\begin{array}{c}\text { Max MBC } \\
(\mathrm{mg} / \mathrm{mL})\end{array}$ & $\begin{array}{c}\mathrm{MBC}_{50} \\
(\mathrm{mg} / \mathrm{mL})\end{array}$ & $\begin{array}{c}\mathrm{MBC}_{90} \\
(\mathrm{mg} / \mathrm{mL})\end{array}$ & $\begin{array}{c}\% \text { Susceptible*} \\
\text { MS }\end{array}$ \\
\hline MB & $9.01 \pm 3.85$ & 3.13 & 12.5 & 12.5 & 12.5 & 100 \\
\hline
\end{tabular}

$\mathrm{MIC}_{50}, \mathrm{MIC}_{90}$, and $\mathrm{MIC}_{100}$-minimal inhibitory concentration needed to inhibit the growth of 50,90 , and $100 \%$ of mutans streptococci and lactobacilli, respectively.

$\left.{ }^{*}\right) 100 \%$ of tested bacteria were susceptible to range of EEP concentrations.

confirmed quantitatively by the AlamarBlue assay. Figures 1 , 2 , and 3 demonstrate the influence of different concentrations of EEP on absorbance changes for mutans streptococci during 1-4-24 hour(s) of EEP activity. Figures 4, 5, and 6 represent the influence of different concentrations of EEP on absorbance changes for Lactobacillus spp. during 1-4-24 hour(s) of EEP activity.

The mean MIC value of EEP was found to be $1.10 \pm$ $0.45 \mathrm{mg} / \mathrm{mL}$ for mutans streptococci and $0.7 \pm 0.29 \mathrm{mg} / \mathrm{mL}$ for lactobacilli (Table 2), while the mean MBC value of EEP was found to be $9.01 \pm 3.85 \mathrm{mg} / \mathrm{mL}$ for mutans streptococci and $5.91 \pm 3.62 \mathrm{mg} / \mathrm{mL}$ for lactobacilli (Table 4 ). The MBC for each sample was a multiple value of its mean MIC. AlamarBlue assay quantitative results for MS group were in correlation with mean MIC values and mean AlamarBlue MIC values for MS group reached, in a vast majority of cases, a double mean MIC value $(2 x)$. Figure 7 presents the percentage reduction of AlamarBlue at 120 minutes for mutans streptococci treated for 24 hours with ethanol extract of propolis at the concentrations from 12.5 to $0.024 \mathrm{mg} / \mathrm{mL}$. AlamarBlue reduction was increasing with incubation time and with lower EEP concentration. Changes of medium colour associated with $\mathrm{AB}$ reduction from blue (oxidized) to pink (reduced) in duplicate wells.
Based on biochemical analysis, EEP phenolic composition generally fits well with that of propolis from different countries, with other organic ingredients. The total polyphenols content was established as $56.18 \pm 7.53 \%$, while the total flavones/flavonols amount and flavanone/dihydroflavonols content amounted to $6.02 \pm 1.23 \%$ and $4.27 \pm 2.36 \%$, respectively (Figure 8 ).

\section{Discussion}

The available in vitro and in vivo studies have reported potential application of propolis in the control of dental caries, especially since it has already been incorporated into commercial domestic products for oral use [12, 33, 34]. The mechanism of antimicrobial action demonstrated by propolis, including cariogenic microorganisms, is controversial and not completely understood. The biological activity of propolis (EEP) may vary according to its composition and seems to be multidirectional [35], involving several mechanisms such as the disorganization of the cytoplasmatic membrane and the cell wall; partial bacteriolysis; formation of pseudomulticellular colonies; and inhibition of protein synthesis [36]. It is assumed that the synergistic effect of main 


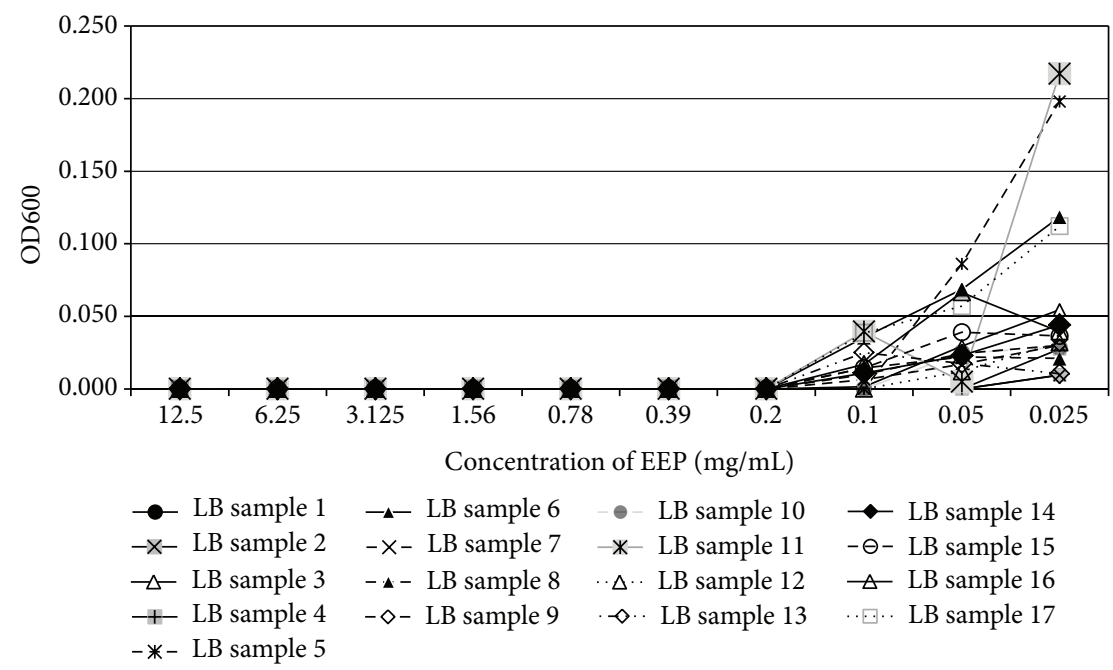

FIGURE 5: The influence of different concentrations of EEP on absorbance changes for Lactobacillus spp. $(n=17)$ during 4 hours of EEP activity (OD600-optical density reading at $600 \mathrm{~nm}$ ).

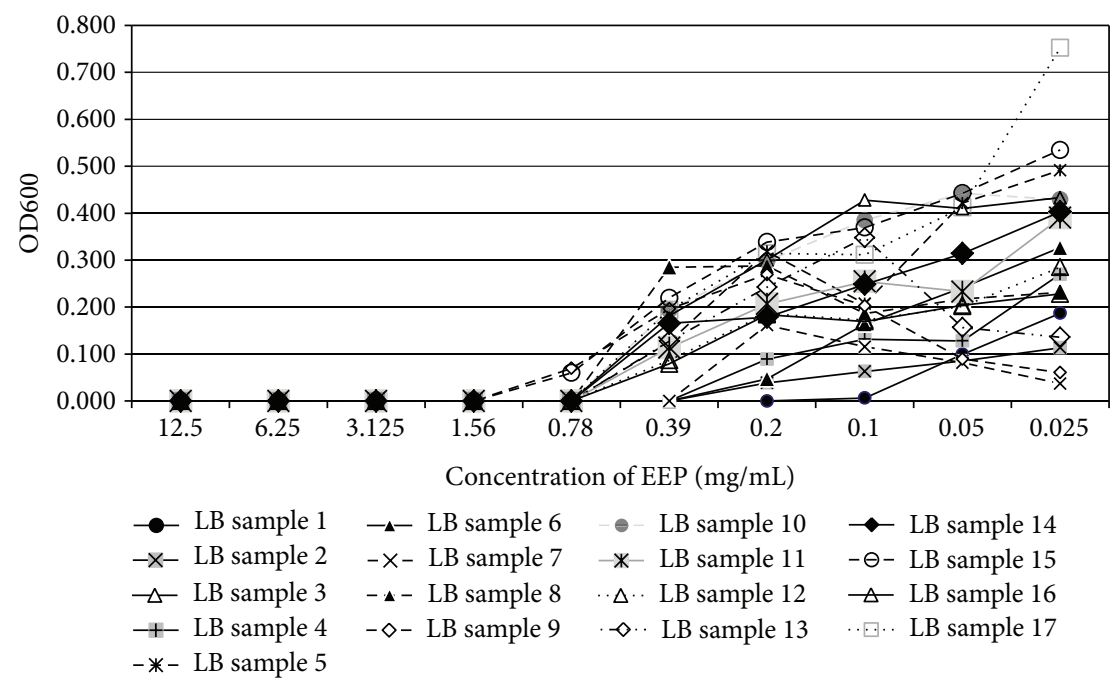

FIGURE 6: The influence of different concentrations of EEP on absorbance changes for Lactobacillus spp. $(n=17)$ during 24 hours of EEP activity (OD600-optical density reading at $600 \mathrm{~nm}$ ).

components of propolis extracts like flavonoids (quercetin, galangin, pinocembrin) and caffeic acid and/or cinnamic acid, probably influence the microbial membrane or cell wall sites, resulting in functional and structural effects [37-40].

The significant variability of the chemical composition of propolis may be a limitation in terms of its quality control, comparability, and reproductive effect [41]. Therefore, a critical analysis of the data available on propolis is essential. Elbaz and Elsayad [13] compared the antimicrobial affect of Egyptian propolis versus propolis from New Zealand on Streptococcus mutans and Lactobacillus spp. in saliva and found that the commercially available propolis from New Zealand, hexane fraction, had the strongest antimicrobial action.

The antimicrobial activity of propolis is widely supported by evidence [42]. Some authors found propolis samples to be active only against gram-positive bacteria and some fungi [15, 25]; however, others confirmed also its weak activity against gram-negative bacteria [8]. The experimental propolis solution investigated by Ozan et al. demonstrated significant effect on gram-positive strains as on gram-negative strains [14] and also showed sufficient effect on gram-negative strains and on Candida strains. This study is in accordance with Sforcin et al. [8], who verified that the growth of Grampositive bacteria was inhibited by low propolis concentrations $(0.4 \%)$, with the MIC ranging from $4.5 \%$ to $8.0 \%$. Drago et al. [43] also observed that in low concentrations propolis reveals bacteriostatic rather than bactericidal activity.

Our findings demonstrated the antibacterial effect of Polish propolis on planktonic mutans streptococci and lactobacilli collected from saliva. The susceptibility of microbiota, which belongs to Streptococcus mutans group and initiating 


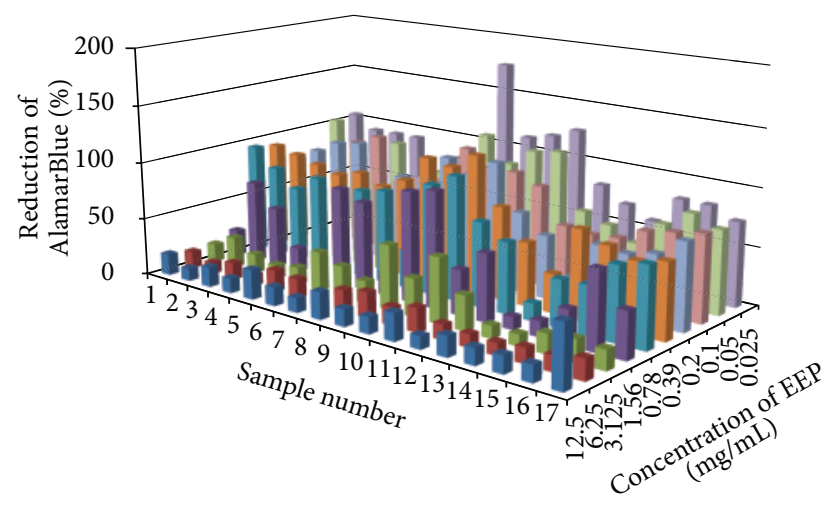

Figure 7: Percentage reduction of AlamarBlue at 120 minutes for mutans streptococci $(n=17)$ treated for 24 hours with ethanol extract of Polish propolis at the concentrations from 12.5 to $0.025 \mathrm{mg} / \mathrm{mL}$.

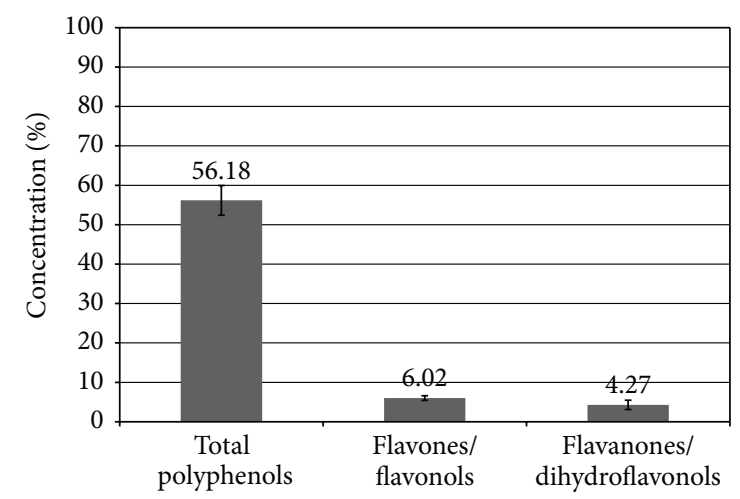

FIgURE 8: Total polyphenol and flavonoid content in investigated propolis sample from Poland. Concentrations (\% standard deviation) of total polyphenols, flavones/flavonols, and flavanones/ dihydroflavonols.

dental caries by teeth demineralization, has been slightly lower than in the case of Lactobacillus spp. $(1.10 \mathrm{mg} / \mathrm{mL}$ mean MIC SM $>0.7 \mathrm{mg} / \mathrm{mL}$ mean MIC LB), the microorganisms responsible for caries progression. Moreover, the minimum MIC value estimated for Lactobacillus spp. was significantly lower than found for $S$. mutans $(0.2 \mathrm{mg} / \mathrm{mL}$ versus $0.39 \mathrm{mg} / \mathrm{mL}$ ). These concentrations can be used in vivo for the prevention of dental caries. The results were opposite to the data presented by other authors [12], who concluded that EEP had a more potent antimicrobial effect on $S$. mutans than on Lactobacillus spp. These results also reflect the fact that oral microorganisms susceptibility to EEP varies and depends on genetic profile of specific individual microflora present in saliva. The research investigating the effect of propolis on dental caries in rats $[44,45]$ confirmed that propolis revealed antimicrobial activity against $S$. sobrinus, $S$. mutans, and $S$. cricetus as well as inhibited both water-insoluble glucan synthesis and glucosyltransferase activity. The investigations revealed the significant influence of Streptococcus mutans counts, which are considered major factors in the progression of cariogenic process $[46,47]$. On the other hand, a single clinical study revealed that propolis was no better than placebo in inhibiting dental plaque formation [48]. Based on in vitro studies, Kim et al. stated that Korean propolis at concentrations $>35 \mu \mathrm{g} / \mathrm{mL}$ has antimicrobial activity against $90 \%$ of the mutans streptococci strains (55 strains) isolated from Koreans [49]. Interestingly, the $\mathrm{MIC}_{50}$ and $\mathrm{MIC}_{90}$ values, representing Korean propolis concentration, were the same for $S$. mutans and S. sobrinus species $(35 \mu \mathrm{g} \cdot \mathrm{mL})$. These results suggest that susceptibility of two main mutans streptococci species to propolis is similar and comparable.

The determination of MIC values depends on technical details that may vary significantly between laboratories and is linked to the bacteria inherent virulence and susceptibility. In our study, the MIC and MBC values were at a relatively low level. Overall, MICs for mutans streptococci determined visually and colorimetrically by AlamarBlue assay were highly correlated with those determined in traditional method. Microplate-based assay which uses AlamarBlue reagent for determination of cells (bacteria) growth seems to be a rapid, low-cost technology for antimicrobial drug screening, which does not require expensive instrumentation. Oxidation-reduction dyes have been used to obtain drug susceptibility measurements for bacteria [50]. Yajko et al. [51] reported as a result of tests with clinical isolates a good correlation between the proportion technique and a novel method with Alamar Blue, a proprietary, resazurin-based [52], and oxidation-reduction indicator which delivered colorimetric MICs for cells, including microbiota.

In the study, investigating antibacterial effects of glassionomer cement containing ethanolic extract of propolis on Streptococcus mutans [1], the authors demonstrated that MIC values of Turkish propolis for S. mutans ATCC 25175 amounted to $25 \mu \mathrm{g} / \mathrm{mL}$. According to disk diffusion test results, the experimental GICs containing EEP exhibited inhibition zones, and the inhibition zone sizes were not dependent upon the concentration of propolis. According to Ophori et al. [53], the EEP at the concentrations of 4, 8, 16, and $32 \mu \mathrm{g} / \mathrm{mL}$ showed strong antimicrobial activity against S. mutans with inhibition zones of $10 \pm 4,12 \pm 4,20 \pm 2$, and $24 \pm 2 \mathrm{~mm}$, respectively, with the use of several dilutions of EEP, ranging between 0.5 and $32 \mu \mathrm{g} / \mathrm{mL}$. Some authors [33] reported that the EEP MIC for Streptococcus mutans ranged from 80 to $40 \mathrm{~mL}$ ( $8.8 \mathrm{mg}$ to $4.4 \mathrm{mg}$ of propolis) and the MIC value of the extract of propolis without alcohol for Streptococcus mutans ranged from 40 to $<10 \mathrm{~mL}$ (4.4 to $<1.1 \mathrm{mg}$ of propolis). They investigated two samples of Brazilian commercially available propolis: ApisFlora $11.0 \%$ ethanolic extract of propolis and Propomax 11.0\% extract of propolis without alcohol.

The association between oral microorganisms found in the saliva as nonadhering populations and as plaque, a microbial biofilm, and specific oral conditions such as dental caries and periodontal disease has been widely described [54]. Clinical studies demonstrated that propolis may prevent caries development. Koo et al. [55] stated that mouth rinse containing propolis showed significant reduction of dental plaque compared to the placebo and also significant inhibition of insoluble polysaccharide formation. Data from clinical studies have also demonstrated reductions in 
Streptococcus mutans collected from saliva in ex vivo conditions. They showed the influence of EEP on plaque index score and insoluble polysaccharide formation, responsible for dental plaque accumulation $[14,34,56,57]$. These results indicate that propolis and/or its compounds are promising cariostatic agents. According to the study results presented by Malhotra et al., the laboratory manufactured propolis mouth rinse showed an effective antimicrobial action only against Streptococcus mutans [12]. The antimicrobial efficacy of propolis against Streptococcus mutans was similar to that of chlorhexidine and the combination of propolis with chlorhexidine.

Because of the fact that the planktonic forms of bacteria in saliva are less resistant than their forms in biofilms (dental plaque), the MIC value does not provide sufficient information concerning the efficacy of antimicrobial agents against infections involving biofilms. It needs to be emphasized that the variation in the chemical composition of propolis due to its geographical distribution is a significant drawback to its routine clinical use as a preventive measure against dental caries. Therefore, more relevant clinical studies are needed to establish quality control protocol for propolis-containing agents, used in accordance with its confirmed activity.

\section{Conclusions}

This study showed a positive inhibitory influence of ethanol extract of Polish propolis with respect to the oral microorganisms growth. The antibacterial effect of propolis seems to be a representation of the synergistic activity of polyphenolics and other organic ingredients. It can be concluded that local measures, for example, lozenges and mouthwashes containing propolis, would be promising agents for dental plaque and caries control, including cariostatic effect. Reduction in oral flora counts obtained by antibacterial efficacy of propolisbased measures may provide an alternative approach for the individuals with high risk of dental caries. Further studies should be performed on propolis biological aspects to establish how the presence of ethanol extract of propolis interferes with the other adjuvants and active anticariogenic substances. Also, additional research is needed to validate clinical results in terms of other bacterial environments (dental plaque).

\section{References}

[1] N. Topcuoglu, F. Ozan, M. Ozyurt, and G. Kulekci, "In vitro antibacterial effects of glass-ionomer cement containing ethanolic extract of propolis on Streptococcus mutans," European Journal of Dentistry, vol. 6, no. 4, pp. 428-433, 2012.

[2] S. Kumazawa, T. Hamasaka, and T. Nakayama, "Antioxidant activity of propolis of various geographic origins," Food Chemistry, vol. 84, no. 3, pp. 329-339, 2004.

[3] A. Kujumgiev, I. Tsvetkova, Y. Serkedjieva, V. Bankova, R. Christov, and S. Popov, "Antibacterial, antifungal and antiviral activity of propolis of different geographic origin," Journal of Ethnopharmacology, vol. 64, no. 3, pp. 235-240, 1999.

[4] A. Russo, V. Cardile, F. Sanchez, N. Troncoso, A. Vanella, and J. A. Garbarino, "Chilean propolis: antioxidant activity and antiproliferative action in human tumor cell lines," Life Sciences, vol. 76, no. 5, pp. 545-558, 2004.

[5] D. Sawicka, H. Car, M. H. Borawska, and J. Nikliński, "The anticancer activity of propolis," Folia Histochemica et Cytobiologica, vol. 50, no. 1, pp. 25-37, 2012.

[6] E. Szliszka, Z. Czuba, J. Bronikowska, A. Mertas, A. Paradysz, and W. Krol, "Ethanolic extract of propolis augments TRAILinduced apoptotic death in prostate cancer cells," EvidenceBased Complementary and Alternative Medicine, vol. 11, Article ID 535172, 11 pages, 2011.

[7] E. Szliszka, Z. P. Czuba, K. Jernas, and W. Król, "Dietary flavonoids sensitize HeLa cells to tumor necrosis factor-related apoptosis-inducing ligand (TRAIL)," International Journal of Molecular Sciences, vol. 9, no. 1, pp. 56-64, 2008.

[8] J. M. Sforcin, A. Fernandes, C. A. M. Lopes, V. Bankova, and S. R. C. Funari, "Seasonal effect on Brazilian propolis antibacterial activity," Journal of Ethnopharmacology, vol. 73, no. 1-2, pp. 243249, 2000.

[9] G. P. Rezende, F. C. Pimenta, and L. R. Costa, "Antimicrobial activity of two Brazilian commercial propolis extracts," Brazilian Journal of Oral Sciences, vol. 5, pp. 967-970, 2006.

[10] F. A. Santos, E. M. A. Bastos, M. Uzeda et al., "Antibacterial activity of Brazilian propolis and fractions against oral anaerobic bacteria," Journal of Ethnopharmacology, vol. 80, no. 1, pp. $1-7,2002$.

[11] Y. K. Park, M. H. Koo, J. A. S. Abreu, M. Ikegaki, J. A. Cury, and P. L. Rosalen, "Antimicrobial activity of propolis on oral microorganisms," Current Microbiology, vol. 36, no. 1, pp. 2428, 1998.

[12] N. Malhotra, S. P. Rao, S. Acharya, and B. Vasudev, "Comparative in vitro evaluation of efficacy of mouthrinses against Streptococcus mutans, Lactobacilli and Candida albicans," Oral Health Preventive Dentistry, vol. 9, no. 3, pp. 261-268, 2011.

[13] G. A. Elbaz and I. I. Elsayad, "Comparison of the antimicrobial effect of Egyptian propolis versus New Zealand propolis on Streptococcus mutans and Lactobacilli in Saliva," Oral Health Preventive Dentistry, vol. 10, no. 2, pp. 155-160, 2012.

[14] F. Ozan, Z. Sümer, Z. A. Polat, K. Er, U. Ozan, and O. Deer, "Effect of mouth rinse containing propolis on oral microorganisms and human gingival fibroblast," European Journal of Dentistry, vol. 11, pp. 195-200, 2007.

[15] M. I. Nieva Moreno, M. I. Isla, N. G. Cudmani, M. A. Vattuone, and A. R. Sampietro, "Screening of antibacterial activity of Amaicha del Valle (Tucuman, Argentina) propolis," Journal of Ethnopharmacology, vol. 68, no. 1-3, pp. 97-102, 1999.

[16] V. Seidel, E. Peyfoon, D. G. Watson, and J. Fearnley, “Comparative study of the antibacterial activity of propolis from different geographical and climatic zones," Phytotherapy Research, vol. 22, no. 9, pp. 1256-1263, 2008.

[17] V. Bankova, R. Christov, A. Kujumgiev, M. C. Marcucci, and S. Popov, "Chemical composition and antibacterial activity of Brazilian propolis," Journal of Biosciences, vol. 50, no. 3-4, pp. 167-172, 1995.

[18] J. S. Bonvehí, F. V. Coll, and R. E. Jordà, “The composition, active components and bacteriostatic activity of propolis in dietetics," Journal of the American Oil Chemists' Society, vol. 71, no. 5, pp. 529-532, 1994.

[19] A. Salatino, E. W. Teixeira, G. Negri, and D. Message, "Origin and chemical variation of Brazilian propolis," Evidence-Based Complementary and Alternative Medicine, vol. 2, no. 1, pp. 3338, 2005. 
[20] M. Blonska, Z. P. Czuba, and W. Krol, "Effect of flavone derivatives on interleukin-1 $\beta$ (IL-1 $\beta$ ) mRNA expression and IL$1 \beta$ protein synthesis in stimulated RAW 264.7 macrophages," Scandinavian Journal of Immunology, vol. 57, no. 2, pp. 162-166, 2003.

[21] W. Krol, S. Scheller, Z. Czuba et al., "Inhibition of neutrophils' chemiluminescence by ethanol extract of propolis (EEP) and its phenolic components," Journal of Ethnopharmacology, vol. 55, no. 1, pp. 19-25, 1996.

[22] W. Krol, Z. Czuba, S. Scheller, J. Gabrys, S. Grabiec, and J. Shani, "Anti-oxidant property of ethanolic extract of propolis (EEP) as evaluated by inhibiting the chemiluminescence oxidation of luminol," Biochemistry International, vol. 21, no. 4, pp. 593-597, 1990.

[23] J. M. Sforcin, "Propolis and the immune system: a review," Journal of Ethnopharmacoogy, vol. 113, no. 1, pp. 1-14, 2007.

[24] V. Dimov, N. Ivanovska, N. Manolova, V. Bankova, N. Nikolov, and S. Popov, "Immunomodulatory action of propolis. Influence on anti-infectious protection and macrophage function," Apidologie, vol. 22, pp. 155-162, 1991.

[25] M. C. Marcucci, "Propolis: chemical composition, biological properties and therapeutic activity," Apidologie, vol. 26, no. 2, pp. 83-99, 1995.

[26] Y. K. Park, M. H. Koo, M. Ikegaki, J. A. Cury, and P. L. Rosalen, "Effects of propolis on Streptococcus mutans, Actinomyces naeslundii and Staphylococcus aureus," Revista de Microbiologia, vol. 29, no. 2, pp. 143-148, 1998.

[27] B. Kedzia, "Chemical composition of Polish propolis-part II. New studies," Postepy Fitoterapii, vol. 10, no. 2, pp. 122-128, 2009.

[28] R. A. Whiley and D. Beighton, "Current classification of the oral streptococci," Oral Microbiology and Immunology, vol. 13, no. 4, pp. 195-216, 1998.

[29] Streptococcus mutans and the mutans streptococci. Oral Environment Online Tutorial, http://www.ncl.ac.uk/dental/ oralbiol/oralenv/tutorials/mutans.htm.

[30] European Committee for Antimicrobial Susceptibility Testing (EUCAST) of the European Society of Clinical Microbiology and Infectious Diseases (ESCMID), "Determination of minimum inhibitory concentrations (MICs) of antibacterial agents by broth dilution. EUCAST discussion document E.dis. 5.1," Clinical Microbiology and Infection, vol. 9, no. 8, pp. 1-7, 2003.

[31] Clinical and Laboratory Standards Institute. Performance standards for antimicrobial disk and dilution susceptibility test: M2A9.2006, "Performance standards for antimicrobial susceptibility testing," 18th informational supplement: M100-S18, Wayne, $\mathrm{Pa}, \mathrm{USA}, 2008$.

[32] W. Maciejewicz and W. Markowski, "Identification of flavonoids aglicones by GC-MS from propolis collected in Southern Poland," in Proceedings of the 2nd International Symposium on Chromatography of Natural Products, vol. 76, p. 34, Kazimierz Dolny, Lublin, Poland, 2000.

[33] G. P. Rezende, F. C. Pimenta, and L. R. Costa, "Antimicrobial activity of two Brazilian commercial propolis extracts," Brazilian Journal of Oral Sciences, vol. 5, pp. 967-970, 2006.

[34] S. A. Liberio, A. L. Pereira, M. J. Araujo et al., "The potential use of propolis as a cariostatic agent and its actions on mutans group streptococci," Journal of Ethnopharmacology, vol. 125, pp. $1-9,2009$.

[35] N. B. Takaisi-Kikuni and H. Schilcher, "Electron microscopic and microcalorimetric investigations of the possible mechanism of the antibacterial action of a defined propolis provenance," Planta Medica, vol. 60, no. 3, pp. 222-227, 1994.
[36] O. K. Mirzoeva, R. N. Grishanin, and P. C. Calder, "Antimicrobial action of propolis and some of its components: the effects on growth, membrane potential and motility of bacteria," Microbiological Research, vol. 152, no. 3, pp. 239-246, 1997.

[37] N. C. Cook and S. Samma, "Flavonoids: chemistry, metabolism, cardioprotective effects and dietary sourses," Journal of Nutritrional Biochememistry, vol. 7, pp. 66-76, 1996.

[38] W. Krol, J. Shani, Z. Czuba, and S. Scheller, "Modulating luminol-dependent chemiluminescence of neutrophils by flavones," Zeitschrift fur Naturforschung C, vol. 47, no. 11-12, pp. 889-892, 1992.

[39] Z. Czuba, W. Krol, S. Scheller, and J. Shani, "Effect of cinnamic and acrylic acids' derivatives on luminol-enhanced chemiluminescence of neutrophils," Zeitschrift fur Naturforschung C, vol. 47, no. 9-10, pp. 753-756, 1992.

[40] W. Krol, Z. Czuba, S. Scheller, Z. Paradowski, and J. Shani, "Structure-activity relationship in the ability of flavonols to inhibit chemiluminescence," Journal of Ethnopharmacology, vol. 41, no. 1-2, pp. 121-126, 1994.

[41] S. Silici and S. Kutluca, "Chemical composition and antibacterial activity of propolis collected by three different races of honeybees in the same region," Journal of Ethnopharmacology, vol. 99, no. 1, pp. 69-73, 2005.

[42] W. Krol, S. Scheller, J. Shani, G. Pietsz, and Z. Czuba, "Synergistic effect of ethanolic extract of propolis and antibiotics on the growth of Staphylococcus aureus," Drug Research, vol. 43, no. 5, pp. 607-609, 1993.

[43] L. Drago, B. Mombelli, E. De Vecchi, M. C. Fassina, L. Tocalli, and M. R. Gismondo, "In vitro antimicrobial activity of propolis dry extract," Journal of Chemotherapy, vol. 12, no. 5, pp. 390-395, 2000.

[44] H. Koo, P. L. Rosalen, J. A. Cury, Y. K. Park, M. Ikegaki, and A. Sattler, "Effect of Apis mellifera Propolis from two Brazilian regions on caries development in desalivated rats," Caries Research, vol. 33, no. 5, pp. 393-400, 1999.

[45] H. Koo, S. K. Pearson, K. Scott-Anne et al., "Effects of apigenin and $t t$-farnesol on glucosyltransferase activity, biofilm viability and caries development in rats," Oral Microbiology and Immunology, vol. 17, no. 6, pp. 337-343, 2002.

[46] S. Duarte, P. L. Rosalen, M. F. Hayacibara et al., "The influence of a novel propolis on mutans streptococci biofilms and caries development in rats," Archives of Oral Biology, vol. 51, no. 1, pp. 15-22, 2006.

[47] M. F. Hayacibara, H. Koo, P. L. Rosalen et al., "In vitro and in vivo effects of isolated fractions of Brazilian propolis on caries development," Journal of Ethnopharmacology, vol. 101, no. 1-3, pp. 110-115, 2005.

[48] M. C. Murray, H. V. Worthington, and A. S. Blinkhorn, "A study to investigate the effect of a propolis-containing mouthrinse on the inhibition of de novo plaque formation," Journal of Clinical Periodontology, vol. 24, no. 11, pp. 796-798, 1997.

[49] M. J. Kim, C. S. Kim, B. H. Kim et al., "Antimicrobial effect of Korean Propolis against the mutans streptococci isolated from Korean," Journal of Microbiology, vol. 49, no. 1, pp. 161-164, 2011.

[50] A. Vasquez, Y. Valdez, R. H. Gilman et al., "Metronidazole and clarithromycin resistance in Helicobacter pylori determined by measuring MICs of antimicrobial agents in color indicator egg yolk agar in a miniwell format," Journal of Clinical Microbiology, vol. 34, no. 5, pp. 1232-1234, 1996.

[51] D. M. Yajko, J. J. Madej, M. V. Lancaster et al., "Colorimetric method for determining MICs of antimicrobial agents for 
Mycobacterium tuberculosis," Journal of Clinical Microbiology, vol. 33, no. 9, pp. 2324-2327, 1995.

[52] M. U. Shiloh, J. Ruan, and C. Nathan, "Evaluation of bacterial survival and phagocyte function with a fluorescence-based microplate assay," Infection and Immunity, vol. 65, no. 8, pp. 3193-3198, 1997.

[53] E. A. Ophori, B. N. Eriagbonye, and P. Ugbodaga, "Antimicrobial activity of propolis against Streptococcus mutans," African Journal of Biotechnology, vol. 9, no. 31, pp. 4966-4969, 2010.

[54] M. Feres, L. C. Figueiredo, I. M. Barreto, M. H. Coelho, M. W. Araujo, and S. C. Cortelli, "In vitro antimicrobial activity of plant extracts and propolis in saliva samples of healthy and periodontally-involved subjects," Journal of the International Academy of Periodontology, vol. 7, no. 3, pp. 90-96, 2005.

[55] H. Koo, P. L. Rosalen, J. A. Cury et al., "Effect of a new variety of Apis mellifera propolis on mutans streptococci," Current Microbiology, vol. 41, no. 3, pp. 192-196, 2000.

[56] V. Dodwad and B. J. Kukreja, "Propolis mouthwash: a new beginning," Journal of Indian Society of Periodontology, vol. 15, no. 2, pp. 121-125, 2001.

[57] S. Sonmez, L. Kirilmaz, M. Yucesoy, B. Yücel, and B. Yilmaz, "The effect of bee propolis on oral pathogens and human gingival fibroblasts," Journal of Ethnopharmacology, vol. 102, no. 3, pp. 371-376, 2005. 


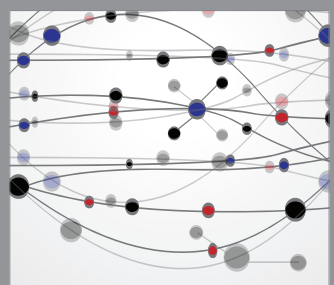

The Scientific World Journal
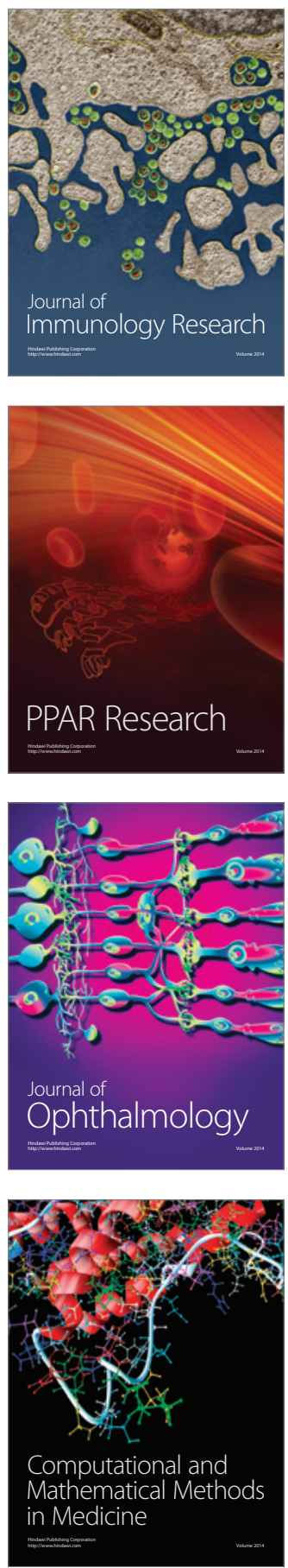

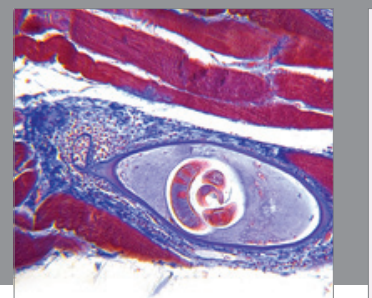

Gastroenterology

Research and Practice
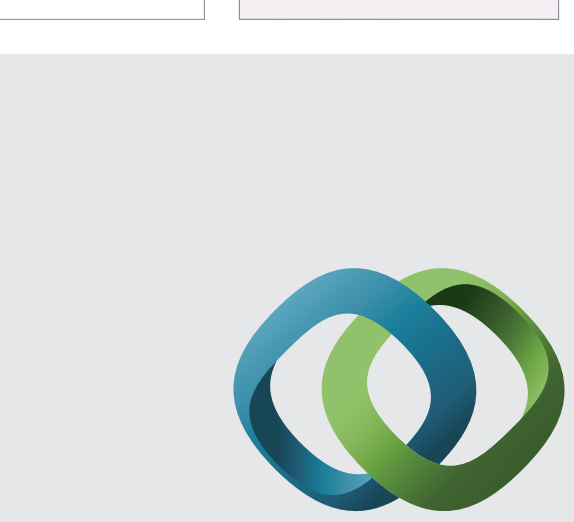

\section{Hindawi}

Submit your manuscripts at

http://www.hindawi.com
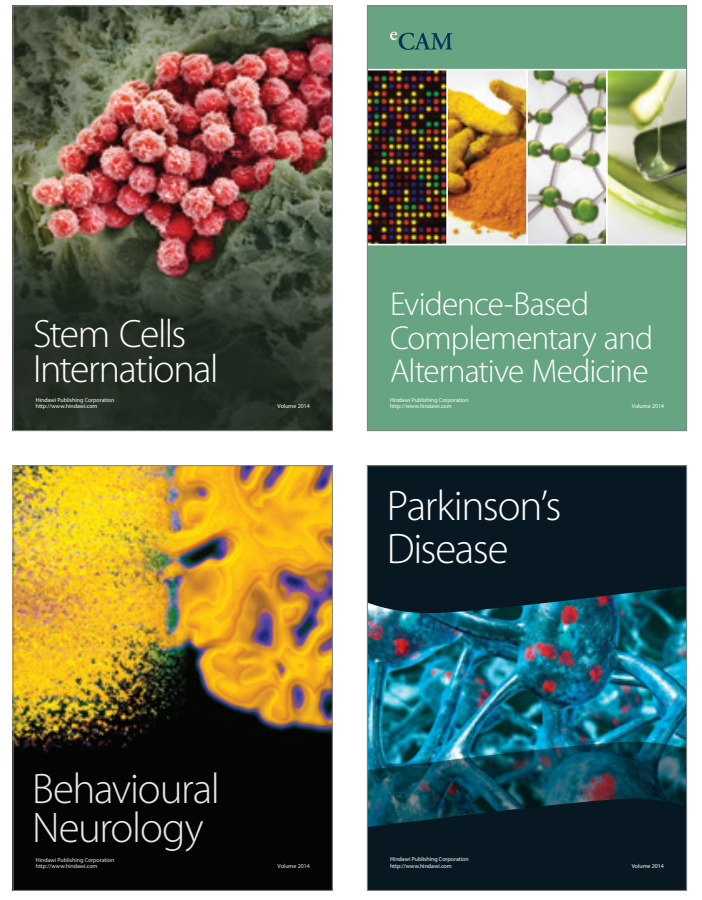
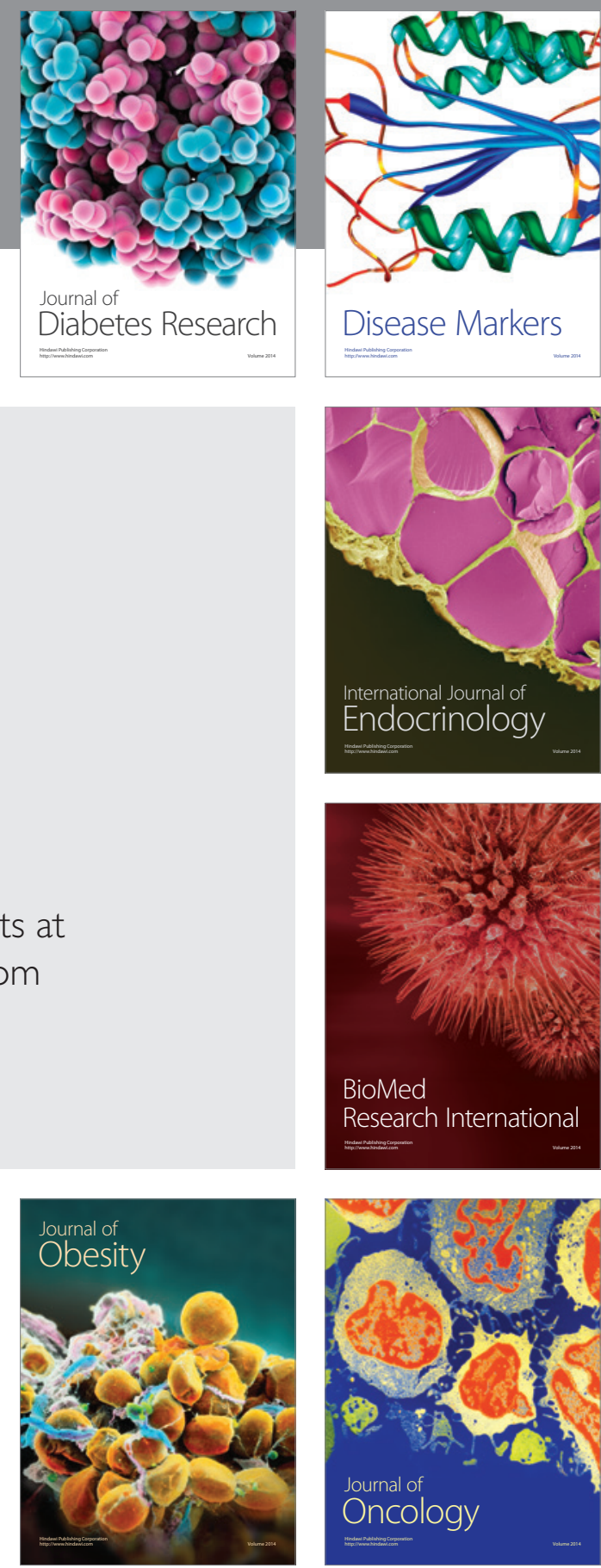

Disease Markers
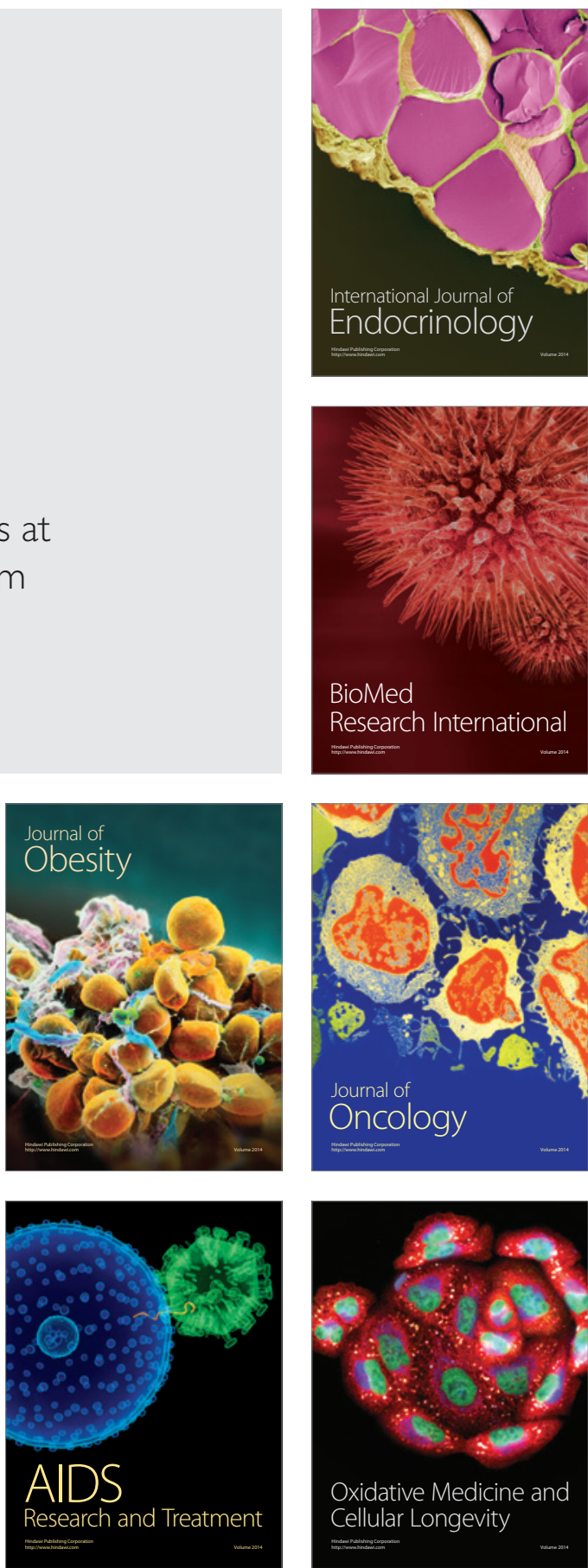